\title{
Rancang Bangun Integrasi Aplikasi Sistem Kehadiran Mahasiswa Menggunakan Kerangka Kerja Laravel Studi Kasus Jurusan Teknik Informatika ITS
}

\author{
Mohammad Shahbana Satriawan, Sarwosri, dan Dwi Sunaryono \\ Departemen Teknik Informatika, Fakultas Teknologi Informasi, Institut Teknologi Sepuluh \\ Nopember (ITS) \\ e-mail: sarwosri@if.its.ac.id
}

\begin{abstract}
Abstrak-Sistem kehadiran mahasiswa merupakan proses pencatatan kehadiran mahasiswa di kelas. Di Teknik Informatika ITS, sistem validasi kehadiran mahasiswa dilakukan secara manual yaitu melakukan tanda tangan di kertas. Hal ini menimbulkan celah kelemahan yaitu terjadi kecurangan dalam sistem kehadiran. Oleh karena itu, diperlukan suatu sistem yang dapat digunakan untuk mengatasi kecurangan dalam sistem kehadiran.Dan juga untuk mengatasi mahasiswa yang sering absen pada perkuliahan, diperlukan suatu sistem yang dapat memonitor hal tersebut. Hasil dari studi ini adalah terbuatnya aplikasi yang mampu memenuhi kebutuhan di Teknik Informatika ITS mengenai sistem informasi kehadiran mahasiswa. Aplikasi ini dapat mengintegrasikan data-data pada aplikasi Web dan Mobile, serta memudahkan proses pencatatan dan perekapan data kehadiran.
\end{abstract}

Kata Kunci-Kehadiran, Laravel, Mobile, Sistem Informasi.

\section{PENDAHULUAN}

$\mathrm{S}_{\mathrm{k}}^{\mathrm{s}}$ ISTEM kehadiran mahasiswa merupakan proses pencatatan kehadiran mahasiswa di kelas. Dengan adanya sistem kehadiran maka dapat membuktikan bahwa mahasiswa tersebut telah berada di dalam kelas. Validasi kehadiran dapat dilakukan dengan berbagai cara. Di Teknik Informatika ITS, sistem validasi kehadiran mahasiswa dilakukan secara manual yaitu melakukan tanda tangan di kertas. Hal ini menimbulkan celah kelemahan yaitu terjadi kecurangan [1] dalam sistem kehadiran atau disebut titip absen. Titip absen merupakan kejadian dimana mahasiswa telah absen tanda tangan namun kenyataannya mahasiswa tersebut tidak hadir di kelas. Dengan menggunakan validasi kehadiran manual, mahasiswa lain bisa memberi tanda tangan kehadiran untuk mahasiswa lain. Oleh karena itu, diperlukan suatu sistem yang dapat digunakan untuk mengatasi kecurangan dalam sistem kehadiran.

Perkembangan teknologi informasi di dunia semakin cepat, khususnya pada teknologi perangkat bergerak dan internet. Akses dan pengambilan informasi dikatakan semakin mudah dan cepat diakses melalui penggunaan perangkat bergerak dan web. Perkembangan ini juga mempengaruhi data sebagai validasi menggantikan kode sandi (password). Validasi merupakan sebuah proses yang wajib ada dimana diperlukan sebuah kebenaran data/informasi, salah satunya adalah proses validasi kehadiran. Proses validasi sudah banyak diterapkan seiring dengan perkembangan teknologi informasi misalnya validasi kehadiran dengan menggunakan alat yang menerima inputan metode fingerprint. Namun kelemahan dari penerapan yang sudah ada adalah kurangnya fleksibilitas dari penerapan ini. Fleksibilitas yang dimaksud adalah teknologi yang digunakan tidak bisa berpindah tempat dan diakses kapanpun. Oleh karena itu, studi ini akan mengimplementasikan sebuah aplikasi mobile berbasis android. Implementasi pada aplikasi mobile diharapkan mampu menambah fleksibilitas dari sistem kehadiran yang sudah ada saat ini.

Hasil yang diharapkan dari pengerjaan studi ini adalah berupa aplikasi mobile yang menggantikan proses sistem kehadiran mahasiswa dari sistem manual melalui tanda tangan pada kertas menjadi sistem online pada aplikasi mobile. Selain itu, dengan aplikasi ini diharapkan juga dapat memberikan kebenaran data kehadirann (data validation) serta mempermudah pemantauan kehadiran mahasiswa di setiap mata kuliah. Selain itu, aplikasi ini juga dapat memberikan informasi kepada orang tua/wali mahasiswa tentang status kehadiran anaknya. Notifikasi akan dikirimkan secara otomatis ke device orang tua/wali jika anaknya tidak masuk dalam perkuliahan. Informasi ini diharapkan dapat membantu orang tua/wali mahasiswa dalam memantau anaknya.

\section{METODE PENELITIAN}

\section{A. Studi Literatur}

Pada tahap ini akan dilakukan penggalian teori-teori yang mendukung penelitian maupun informasi lain yang menunjang pelaksanaan penelitian.

\section{B. Wawancara dan Identifikasi Kebutuhan}

Tahapan ini bertujuan untuk mengumpulkan informasi mengenai kebutuhan pengguna yang diamati dalam penelitian yaitu Jurusan Teknik Informatika Informasi yang akan digali seputar sistem kehadiran mahasiswa, fitur-fitur yang diperlukan, dan data-data yang dibutuhkan

\section{Perancangan Sistem}

Dari hasil studi literatur dan hasil wawancara dibuat 
deskripsi umum sistem serta dilakukan analisa kebutuhan sistem, selain itu juga dilakukan perancangan awal aplikasi yang akan dibuat, sehingga akan dihasilkan disain antarmuka dan proses yang siap untuk diimplementasikan.

\section{Pembangunan Sistem}

Pada tahap ini merupakan tahap yang paling banyak memerlukan waktu karena model dan rancangan aplikasi yang telah dibuat diimplementasikan dengan menggunakan teknologi Web berbasis kerangka kerja Laravel dan aplikasi perangkat bergerak berbasis Android.

\section{E. Uji Coba Sistem}

Pada tahapan ini aplikasi diujicobakan kepada user, dan dipastikan bahwa fungsi-fungsi yang ada telah berjalan dengan baik sesuai dengan design yang telah dibuat. Serta dilakukannya uji penerimaan pengguna pada masing-masing aktor

\section{TINJAUAN PUSTAKA}

\section{A. Sistem Kehadiran}

Sistem kehadiran adalah sistem yang digunakan dalam pengambilan data guna mengetahui jumlah kehadiran pada suatu acara. Setiap kegiatan yang membutuhkan informasi mengenai peserta tentu akan melakukan konfirmasi jika telah hadir. Hal ini juga terjadi pada proses kegiatan perkuliahan mahasiswa. Kegunaan sistem kehadiran ini terjadi pada pihak mahasiswa dan pihak dosen maupun kampus. Sistem kehadiran dapat dilakukan dengan berbagai cara,

Di Teknik Informatika ITS, Sistem kehadiran mahasiswa dilakukan secara manual yaitu melakukan tanda tangan di kertas daftar hadir mahasiswa. Salah satu kegunaan sistem kehadiran bagi mahasiswa adalah untuk syarat untuk mengikuti ujian mata kuliah, sedangkan bagi pihak dosen atau kampus, sistem kehadiran diperlukan sebagai salah satu bahan evaluasi kepada kepuasaan mahasiswa terhadap suatu mata pelajaran dan pembuatan tolak ukur ke depan guna pemberian ilmu yang lebih baik.

\section{B. Laravel}

Laravel adalah framework PHP yang dikembangkan pertama kali oleh Taylor Otwell. Fitur-fitur laravel yang akan dipergunakan pada Aplikasi ini adalah

1. HTTP Response, termasuk JSON Response untuk mengintegrasikan Aplikasi Mobile dengan Web. Digunakan untuk proses Login dan pengambilan data dari Database Server. Juga akan dibuat sebuah web service untuk menghubungkan antara Aplikasi Mobile dan Server. Aplikasi Mobile akan mengirimkan JSON Request kepada API, yang kemudian akan dikembalikan dalam bentuk JSON Response seperti pada Error! Reference source not found.

2. RestFul Routing, Memudahkan pengguna untuk mengelola request. Karena menggunakan metode standar REST seperti GET, POST, PUT, PATCH, DELETE, STORE. Routing dalam laravel sangat membantu juga untuk debugging dan developing.
3. Fitur Autentikasi. Laravel telah menyediakan keamanan dalam hal autentikasi, seperti enkripsi, autentikasi password, password reminder dan reset.

4. Fitur Schema Builder untuk berbagai database

5. Fitur Migration \& Seeding untuk berbagai database

6. Fitur Query Builder yang powerful

7. Eloquent ORM (Object Relational Mapping). Untuk mempermudah pemanggilan data melalui model.

8. Scheduling Jobs, Untuk melakukan perintah yang akan dilakukan secara otomati dan terjadwal [1]

9. Laravel FCM (Firebase Cloud Messaging) untuk pembuatan dan pengiriman push notification [2]

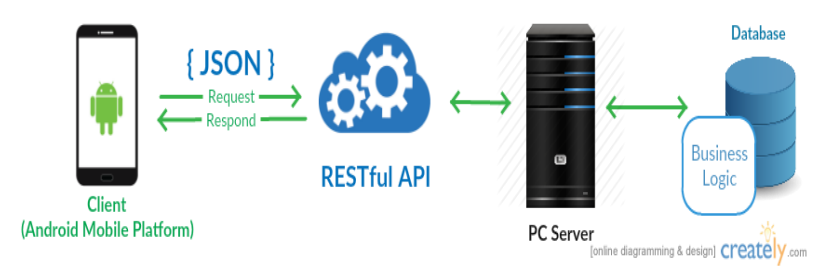

Gambar 1. Pertukaran Data melalui RESTful API

\section{ANALISIS DAN PERANCANGAN SISTEM}

\section{A. Deskrpsi Umum Sistem}

Pada awalnya, karyawan Tata Usaha harus melakukan proses login ke dalam aplikasi web Sistem Kehadiran Mahasiswa terlebih dahulu untuk pengaturan jadwal dan daftar mahasiswa. Kemudian pada saat mata kuliah akan berlangsung, Dosen akan melakukan proses login ke dalam aplikasi mobile atau web untuk melakukan pengaktifan mata kuliah yang akan berlangsung, atau melakukan penjadwalan ulang. Kemudian apabila dosen telah melakukan pengaktifan, Proses pencocokan lokasi diadakannya kuliah dan lokasi mahasiswa akan dilakukan. Apabila lokasi cocok, maka kemudian mahasiswa dapat memilih dua cara untuk melakukan validasi kehadiran. Face Recognition, pencocokan tandatangan atau pencocokan suara. Setelah suatu proses validasi absen berhasil, maka secara real time status kehadiran mahasiswa akan terupdate pada server, dan dapat dilihat pada Aplikasi mobile milik Dosen. Dan juga melalui Aplikasi Web, Dosen, Karyawan dapat melihat laporan kehadiran perkuliahan. Orang tua/wali akan mendapatkan notifikasi apabila anaknya tidak masuk dalam perkuliahan. Selain itu juga dapat melihat rekap kehadiran anaknya melalui aplikasi web

\section{B. Use Case Diagram}

Berdasarkan analisis spesifikasi kebutuhan fungsional dan analisis aktor dari sistem, dibuat kasus penggunaan sistem. Kasus penggunaan digambarkan dalam diagram kasus penggunaan pada Gambar 2

\section{Perancangan Arsitektur Sistem}

Pada pembuatan aplikasi ini, menggunakan kerangka kerja Laravel, yang menggunakan konsep MVC (Model, View Controller). Browser digunakan untuk mengakses aplikasi Web dan Smartphone digunakan untuk mengakses aplikasi mobile. Proses bisnis yang ada pada aplikasi ditampilkan melalui antarmuka sistem. Gambar 3 


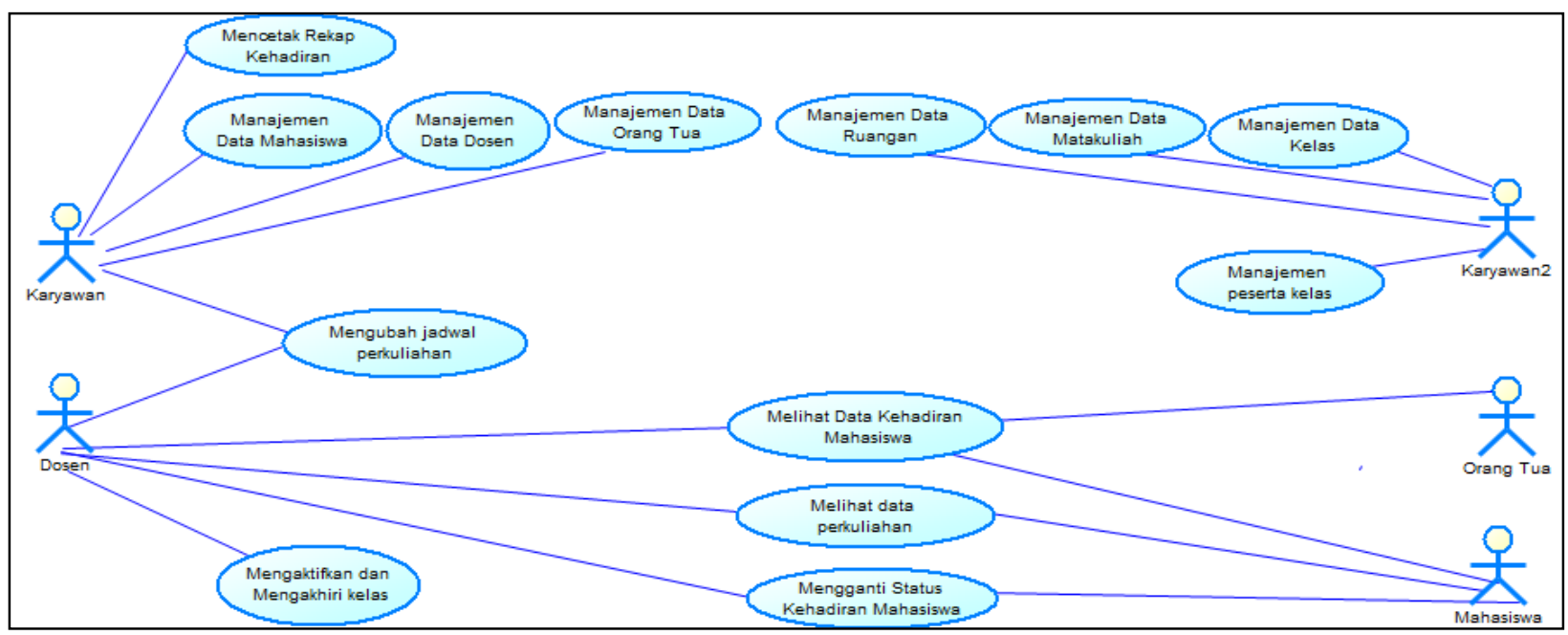

Gambar 2. Diagram Kasus Penggunaan

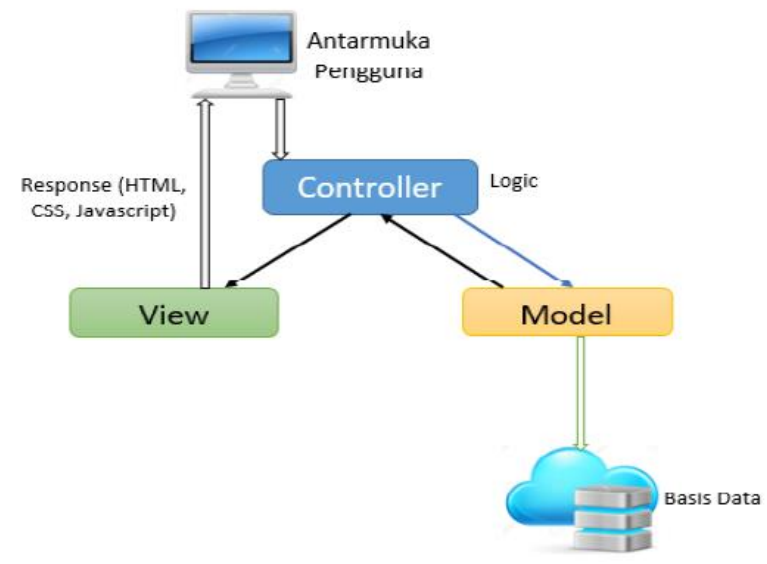

Gambar 3. Arsitektur Sistem

\section{PENGUJIAN DAN EVALUASI}

Ada dua pengujian yang dilakukan pada studi ini, yaitu pengujian fungsionalitas dan pengujian penerimaan pengguna

\section{A. Pengujian Fungsionalitas}

Pengujian yang dilakukan merupakan pengujian fungsionalitas yang menggunakan metode blackbox. Metode blackbox merupakan metode dimana pengujian ditekankan pada pola input dan output yang sesuai dengan skenario. Pengujian dilakukan dengan mengacu kasus penggunaan yang telah dijelaskan pada bab analisis dan perancangan sistem

Berdasarkan hasil pengujian yang telah dilakukan, diketahui bahwa semua kebutuhan fungsional yang ada telah berjalan sesuai skenario.

\section{B. Pengujian Penerimaan Pengguna}

Pengujian penerimaan pengguna ini dilakukan untuk mengetahui tingkat kecocokan aplikasi terhadap pengguna dan keadaan sebenarnya. Kegunaan yang diuji meliputi fitur-fitur yang ada pada tiap aktor. Setelah pengujian selesai, pengguna diminta untuk mengisi kuesioner yang diberikan. Penilaian kuesioner ini memiliki skala 1-5 dimana semakin kecil angka skala yang dipilih berarti semakin tidak setuju sedangkan semakin besar nilai angka skala yang dipilih berarti semakin setuju dengan pernyataan kuesioner.

Berdasarkan hasil pengujian yang telah dilakukan menghasilkan nilai rata-rata 4,36 pada aktor mahasiswa, 4,18 pada aktor dosen, dan 4.05 pada aktor orang tua.

\section{KESIMPULAN}

Rancang bangun integrasi aplikasi mobile dan web sistem kehadiran mahasiswa berbasis kerangka kerja laravel berhasil dibuat. Data yang diterima, diolah dan dikirimkan bernilai benar. Laravel sangat baik digunakan sebagai penyedia RestAPI karena kemudahan dalam Query data melalui Eloquent.Laravel. Dan Firebase Cloud Messaging sangat membantu dalam pembuatan dan pengiriman notifikasi karena sangat cepat dan mudah.

Untuk pengembangan dan penelitian selanjutnya dari aplikasi yang dibuat adalah perlunya dibuat mekanisme penyimpanan data-data di semester lalu.

\section{DAFTAR PUSTAKA}

"Task Scheduling - Laravel - The PHP Framework For Web Artisans," $2017 . \quad$ [Online]. Available: https://laravel.com/docs/5.4/scheduling. [Accessed: 05-Jun2017].W.-K. Chen, Linear Networks and Systems (Book style).\%09Belmont, CA: Wadsworth (1993) 123-135.

[2] "brozot/laravel-fcm - Packagist," 2017. [Online]. Available: https://packagist.org/packages/brozot/laravel-fcm. 